FILOZOFIA

Roč. 75,2020, č. 8

DOI: https://doi.org/10.31577/filozofia.2020.75.8.7

\title{
AKÉ REPREZENTÁCIE A KOGNITÍVNE MECHANIZMY UMOŽŇUJÚ KUMULATÍVNU KULTÚRU?
}

JURAJ BÁNOVSKÝ, Filozofický ústav Slovenskej akadémie vied, Bratislava, SR; Univerzita Komenského v Bratislave, Fakulta matematiky, fyziky a informatiky, Katedra aplikovanej informatiky, Bratislava, SR

BÁNOVSKÝ, J.: What Kinds of Representations and Cognitive Mechanisms Enable Cumulative Culture?

FILOZOFIA, 75, 2020, No 8, pp. $706-722$

\begin{abstract}
The objective of the article is to explore representations and cognitive mechanisms that provide a basis for cumulative cultural learning. The paper examines research of imitation and natural pedagogy with focus on the role of decoupled representations and ostensive signals in the transmission of cognitively opaque cultural knowledge. The article aims to show that the theory of metarepresentations provides a useful explanatory framework for the explanation of emergence and development of abilities that enable acquisition of cultural practices and generic knowledge. The paper suggests that the application of the framework can contribute to the analysis of processes involved in interactions that facilitate early cultural learning.
\end{abstract}

Keywords: Cumulative culture - Imitation - Natural pedagogy - Metarepresentations

\section{1. Úvod}

Ch. Y. Zarka (2018) vo svojej nedávno publikovanej štúdii uviedol, že kognitívne vedy radikálne spochybňujú pojem l'udskej výnimočnosti. S týmto konštatovaním sa dá do vel'kej miery súhlasit', ked’že v priebehu posledných dekád vedci odhalili, že viaceré schopnosti, ktoré boli považované za špecificky l’udské, sú v istej forme prítomné aj u iných živočíšnych druhov (prehl'ad možno nájst' napríklad v Shettleworth 2009). Napriek tomu stále zostáva nástojčivou otázka, v čom sú l’udia iní a čo im umožnilo dosiahnut' pokrok napríklad v technike, vo vede a umení, teda výsledky, ktoré len t’ažko možno porovnávat's výsledkami činností iných druhov.

V súčasnosti sa ako jeden z najvýraznejších kandidátov na vysvetlenie tohto úspechu ukazuje schopnost' tvorit' kumulatívnu kultúru (Mesoudi a Thornton 2018). Vytváranie kumulatívnej kultúry pomohlo l'ud'om prispôsobit' sa rozmanitým prostrediam a žit'v často vel'mi nehostinných podmienkach, ked’že umožnilo objavit' riešenia adaptačných problémov nielen prostredníctvom náhody alebo individuálneho úsilia, 
ale aj na základe šírenia poznatkov v skupine. Táto schopnost' je jednou z charakteristických čŕt l’udskej mysle a bezpochyby prispela k evolučnému úspechu nášho druhu. Samozrejme, treba podotknút', že viedla i k d’alekosiahlym zmenám globálneho ekosystému, $\mathrm{v}$ súvislosti s ktorými sa $\mathrm{v}$ súčasnosti dostáva do popredia termín antropocén (pozri napr. St’ahel 2019). Ak je kumulatívna kultúra tým, čo nás zásadným spôsobom odlišuje od ostatných organizmov (Hill a kol. 2009), nakol'ko umožňuje vysvetlit' technologický pokrok, ale aj rozmanitost' kultúr a kultúrnych noriem, tak by k základným otázkam výskumu zameraného na špecificky l’udské schopnosti malo patrit' aj riešenie problému, ako je vôbec možné, že sme schopní prenášat' naakumulované kultúrne poznatky z generácie na generáciu.

Pre kumulatívnu kultúru je príznačné, že pri prenose dochádza $\mathrm{k}$ dôslednému uchovávaniu prenášaných poznatkov a $\mathrm{k}$ ich postupnej modifikácii. $\mathrm{V}$ tejto súvislosti sa často spomína efekt západky (ratchet effect). Analogicky k fungovaniu rohatky a západky, ktoré zabezpečujú, aby dochádzalo $\mathrm{v}$ istých mechanizmoch k pohybu len jedným smerom, tak aj v prípade vývoja kultúrnych foriem možno za istých okolností povedat', že „každá modifikácia zostane stabilizovaná, až kým nedôjde k d’alšej modifikácii“ (Tomasello a kol. 1993, 495). Ak v skupine nedôjde k prerušeniu tradície (napr. vplyvom výraznej zmeny životného prostredia či v dôsledku prílišného poklesu populácie), tak by nemalo dôjst' k strate získaných poznatkov. Mechanizmus, ktorý umožňuje uchovávanie, postupné modifikovanie a zvyšovaní efektivity a komplexnosti činností a ich produktov, sa evidentne zakladá na dôkladnom sociálnom učení, pričom platí, že poznatky získané týmto spôsobom sú kvantitatívne a kvalitatívne na vyššej úrovni ako tie, ktoré môže jednotlivec dosiahnut' na základe individuálneho učenia.

Je zrejmé, že otázku, či sa tento mechanizmus prejavuje len u l'udí, nemožno zodpovedat' bez porovnania s inými druhmi. Podl'a viacerých vplyvných autorov (pozri napr. publikáciu Laland a Galef (eds.) 2009) dochádza u iných druhov k šíreniu poznatkov len $\mathrm{v}$ obmedzenej forme a procesy, ktoré prenos podmieňujú, pravdepodobne neumožňujú postupné zdokonal'ovanie. Napríklad Tomasello $(2009,211)$ tvrdí, že máme len vel'mi slabú a obmedzenú evidenciu kumulatívnej kultúry u šimpanzov a je možné, že žiadne z ich správaní nepatrí do tejto kategórie. Na druhej strane v priebehu poslednej dekády bol názor vyjadrujúci presvedčenie o l'udskej výnimočnosti vystavený kritike, ked’že aj u iných živočíšnych druhov boli odhalené typy správania, ktoré podl'a autorov niektorých štúdií poukazujú na šírenie kultúry (odkazy na relevantné štúdie možno nájst' napr. v Mesoudi a Thornton 2018). No aj keby sme prijali záver, že nie sme jediný druh schopný tvorit' kumulatívnu kultúru, tak je stále potrebné vysvetlit' špecifický stupeň, ktorý táto schopnost' dosiahla u l'udí, ked’že nám umožňuje generovat' neporovnatel'ne komplexnejšie tradície postupov a poznatkov. 
V súčasnej diskusii o pôvode a povahe kultúrnej evolúcie je zastúpené pomerne široké spektrum názorov, ktoré sa líšia vo viacerých konceptuálnych a metodologických aspektoch, no predovšetkým $\mathrm{v}$ ponímaní interakcie medzi génmi a prostredím a v chápaní klúčových mechanizmov umožňujúcich šírenie poznatkov. Najvýraznejšie zastúpené prístupy sa usilujú vysvetlit' vzorce l'udského správania z pohl'adu evolúcie (vychádzajú napr. z teórie podvojnej dedičnosti, evolučnej psychológie či memetiky) a nadväzujú na diskusiu súvisiacu s výskumom sociobiológie, ktorú výrazne ovplyvnilo dielo E. O. Wilsona (1975). Tento text sa však nebude zaoberat' všeobecnou otázkou, do akej miery je vhodné aplikovat' princípy evolučnej teórie na rozvoj kultúry (napr. v Mesoudi a kol. 2006), respektíve problémom, či je vôbec vhodné hovorit' o kultúrnej evolúcii a či nejde len o zdanlivú podobnost' medzi rozdielnymi sférami, pričom aplikácia princípov evolúcie na oblast' kultúry môže pôsobit' zavádzajúco a vytvárat' viac problémov ako riešení (Pinker 1997). V príspevku tiež nebude priestor venovat' sa pokusom vysvetlit' rozvoj kumulatívnej kultúry na základe postulovania replikátorov (mémov), ako sa o to pokúša napríklad Dawkins (1976) či Dennett (1990), a teda ani kritike tejto pozície (Lewens 2006). V štúdii sa zameriam skôr na analýzu súčasného empirického výskumu, predovšetkým v oblasti vývinovej psychológie, a pokúsim sa špecifikovat' typy reprezentácií a kognitívnych mechanizmov, ktoré mohli prispiet' $\mathrm{k}$ rozvoju kumulatívnej kultúry, založenej na efektívnom sociálnom učení (zohrávajúcom kl'účovú úlohu napríklad v rámci teórie kultúrnej evolučnej psychológie, ktorú zastáva C. Heyesová (2018), alebo v rámci prístupu, ktorý obhajuje K. Sterelny (2012)).

\section{2. Čo umožňuje kumulatívnu kultúru?}

Riešenie načrtnutého problému sa na prvý pohl'ad môže zdat' jednoduché. Je totiž zrejmé, že prenos poznatkov medzi jednotlivcami umožňuje komunikácia. Dôležitým faktom je tiež to, že len l'udia používajú na komunikáciu jazyk, prostredníctvom ktorého možno za pomoci syntaktických pravidiel vytvárat' neobmedzené množstvo výpovedí. Schopnost' tvorit' komplexné hierarchické jazykové štruktúry bezpochyby podporuje flexibilitu myslenia a prispieva $\mathrm{k}$ schopnosti inovovat' a šírit' poznatky, čím podmieňuje rozvoj kumulatívnej kultúry. Máme však dostatočnú evidenciu, na základe ktorej môžeme tvrdit', že gramatický jazyk sa objavil neskôr ako prvé prejavy kumulatívnej kultúry (Hiscock 2014; Stout 2011), a teda priamo neprispel k rozvoju najstarších industrií, v ktorých sa už prejavili isté znaky pokroku. Ako pravdepodobné sa skôr javí, že práve zmeny vo výrobe nástrojov a prenose poznatkov, ktoré sa týkali ich výroby, mohli zohrat' zásadnú úlohu pri rozvoji schopností umožňujúcich produkciu gramatického jazyka (pozri napr. Sterelny 2016). V takom prípade je zmysluplné 
sústredit' sa na schopnosti, vd’aka ktorým dochádza k prenosu kultúrnych poznatkov už na úrovni, ktorá nevyžaduje gramatický jazyk.

Môžeme predpokladat', že kognitívne procesy umožňujúce kultúrne učenie predstavovali pre jednotlivcov a pre skupiny, do ktorých patrili, evolučnú výhodu, ked’že tí, ktorí mali vyššiu schopnost' učit' sa od expertov, boli úspešnejší pri zabezpečovaní obživy a mali vyššiu šancu prežit'. Tento úspech mohol mat' za následok selekciu čŕt, vd’aka ktorým dochádzalo $\mathrm{k}$ efektívnejšiemu prenosu poznatkov, a teda by sa dalo usudzovat', že v prípade kultúrneho učenia ide o evolučnú adaptáciu, ktorá sa vyvíjala postupne. Prítomnost' príslušných vrodených mechanizmov by sa $\mathrm{v}$ tom prípade mala prejavovat' $v$ ontogenéze ich postupným dozrievaním. $Z$ tohto dôvodu je dôležité skúmat' problém $\mathrm{z}$ vývinovej a $\mathrm{z}$ komparatívnej perspektívy - treba pochopit', ako sa táto schopnost' objavuje a vyvíja, respektíve v čom sa l'udská vývinová krivka odlišuje od vývinu iných druhov, v čom je špecifická. Skôr ako sa detailnejšie sústredíme na zodpovedanie týchto otázok, je vhodné špecifikovat' charakter schopností, ktorých prejavy by mal výskum odhalit'.

Výskum by sa mal týkat’ špecifického typu sociálneho učenia, ktoré umožňuje dostatočne verný prenos poznatkov v rámci skupiny. Mechanizmus podmieňujúci tento typ sociálneho učenia by mal $\mathrm{v}$ prípade učenia sa postupu pri vykonávaní istej činnosti umožňovat' subjektu rozpoznat' motorickú reprezentáciu činnosti vykonanej sledovanou osobou (od ktorej sa subjekt učí), preniest' ju do vlastného rámca a potom ju vykonat'. Na to, aby sa tento proces mohol uskutočnit', musí príst' k spárovaniu vizuálnej reprezentácie pozorovanej činnosti a motorickej reprezentácie následne vykonanej činnosti na základe vzájomnej podobnosti. Je teda nutné, aby mali obe reprezentácie spoločné základné štruktúrne charakteristiky. Nejde o jednoduchý problém, ked’že pri mapovaní reprezentácí́ z jedného systému do druhého, zo senzorického formátu do motorického, ide o dva odlišné typy reprezentácií. Okrem transformácie modalít pri prenose dochádza aj $\mathrm{k}$ transformácii $\mathrm{z}$ alocentrického do egocentrického rámca (z rámca, ktorý sa vzt’ahuje na pozorovanú osobu, do rámca subjektu prijímajúceho informáciu). Možným riešením tohto problému by mohli byt' napríklad zrkadliace neuróny, ktoré by zabezpečili priamy prenos z jedného formátu do druhého. Vysvetleniu pomocou zrkadliacich neurónov sa $\mathrm{v}$ tomto kontexte nebudeme podrobnejšie venovat', ide o komplexný problém, no treba podotknút', že v ostatnom čase bolo viackrát kritizované, pretože neponúka vysvetlenie, ale skôr len postuluje zázračný mechanizmus (zrkadlenia), ktorý nerieši problém formovania korešpondencie medzi percepčnými a motorickými reprezentáciami (Heyes 2018, 121). Ďalšou podmienkou úspešného šírenia a uchovávania kultúrnych poznatkov je to, aby reprezentácia danej činnosti bola pomerne trvalá, aby bola vybavitel'ná aj neskôr. Kopírovanie činností by malo byt' dostatočne presné, aby umožňovalo zabezpečit' stabilitu vzorca správania 
a aby nedošlo k znehodnoteniu informácie o tom, ako vykonávat' danú činnost', a teda aj reprezentácia danej činnosti by mala byt' uchovaná tak, aby bol zabezpečený pomerne vysoký stupeň presnosti. Na druhej strane by však takáto reprezentácia mala byt' aj pomerne flexibilná a všeobecná, aby bola použitel’ná aj v iných podobných kontextoch. Ako je zrejmé, na mechanizmus, ktorý by umožňoval efektívny prenos poznatkov, sú kladené pomerne vysoké nároky. Spomedzi stratégií sociálneho učenia splńa uvedené podmienky najskôr proces, ktorý sa väčšinou označuje ako imitácia, teda schopnost' vykonávat' činnost' podobnú tej, ktorú vykonal niekto, koho imitujúci subjekt pozoroval.

\section{Imitácia}

V nasledujúcej časti sa budem zaoberat' výskumom imitácie, ked’že môžeme predpokladat', že práve táto schopnost' zohrávala zásadnú úlohu pri rozvoji kumulatívnej kultúry. Pokúsim sa načrtnút' teórie a dôležité experimenty, ktoré prispeli $\mathrm{k}$ jej hlbšiemu pochopeniu. Za jednu z najvplyvnejších štúdií o povahe imitácie možno považovat' Meltzoffov text z roku 1988, v ktorom sa zameral na schopnost' detí napodobňovat' činnosti, ktoré sú pre ne celkom nové, s ktorými sa ešte nestretli. Štrnást'mesačné deti sledovali v experimentálnych podmienkach dospelú osobu, ktorá zapla špeciálne upravené svietidlo umiestnené na stole dotykom čela. Po jednom týždni boli deti pozvané spät' do laboratória, kde im opät' ukázali špeciálnu lampu, no až vtedy mali možnost' prvýkrát ju samy zapnút'. Prekvapujúcim výsledkom tohto experimentu bolo, že signifikantná väčšina detí zapla svetlo dotykom hlavy. Reakcie štrnást'mesačných detí poukazovali na pomerne zložitú schopnost', ktorá im umožňuje ,interne reprezentovat' činnosti, ktoré videli vykonávat' dospelých, a sú motivované použit' tieto reprezentácie, aby nimi riadili svoje d’alšie správanie aj v prípade, že ho majú vykonat’ so značným časovým odstupom“ (Meltzoff 1988).

Ďalšie experimenty, ktoré sa sústredili na povahu imitácie u predverbálnych detí, odhalili, že ide ešte o výrazne zložitejší proces, pri ktorom nedochádza len $\mathrm{k}$ jednoduchému kopírovaniu činnosti pozorovanej osoby vystupujúcej v pozícii experta. Pomocou modifikovanej verzie spomínaného experimentu sa Gergely a kol. (2002) pokúsili pochopit', či za zdanlivo iracionálnym správaním predsa len nemožno nájst' skrytú racionalitu. Autori štúdie skúmali reakciu detí na dva typy situácií. V prvej situácii mala pozorovaná osoba vol'né ruky, a teda jej nič nebránilo, aby ich použila pri zapnutí lampy. V druhej situácii mala ruky skryté pod dekou, do ktorej bola zabalená, pretože sa tvárila, že jej je zima, a preto nemohla svetlo zapnút' rukou. Porovnanie výsledkov vykonaných $\mathrm{v}$ oboch podmienkach ukázalo, že deti imitovali dotyk hlavou častejšie, ak mala pozorovaná osoba vol'né ruky (69\%), ako ked' mala ruky skryté (21\%). Jedným zo záverov experimentu je, že deti pri porozumení činností iných 
aktérov a pri ich nasledujúcom imitovaní predpokladajú, že sledovaný aktér sa správa racionálne a jeho správanie je výsledkom zhodnotenia rôznych faktorov, ako napríklad prostriedkov, prekážok či ciel’a. To znamená, že deti chápu, že za daných okolností je pre sledovanú osobu najracionálnejšie dosiahnut' ciel' najjednoduchším možným spôsobom, a ak to tak nerobí, musí mat' dobrý dôvod, prečo činnost' vykonáva inak. Ak je dôvod zrejmý, napríklad, že jej je zima, ruky má skryté a nie sú použitel'né, tak sú deti schopné vyhodnotit' danú situáciu a pochopit', že osobe ide o dosiahnutie ciel’a a zvolila si najracionálnejšie riešenie za daných podmienok - v tomto prípade sa deti rozhodnú pre priame dosiahnutie ciel’a (emuláciu) činnosti a na zapnutie lampy použijú skôr ruku. Ak však dôvod, prečo sledovaná osoba koná prekvapivým spôsobom, nie je zrejmý (má vol’né ruky a nič jej nebráni zapnút lampu rukou), tak deti vyhodnotia danú situáciu ako prejav toho, že musí mat' nejaký (priamo nepozorovatel'ný) dôvod, prečo činnost' nevykonáva najjednoduchším spôsobom. V tomto prípade sa riadia skôr tým, že je vhodnejšie činnost' imitovat' a napodobňovat' aj tie prvky správania, ktoré pôsobia ako irelevantné. Uvedený experiment teda ukazuje, že imitácia ,je selektívny, inferenčný proces, ktorý si vyžaduje zhodnotenie racionality prostriedkov použitých pri dosahovaní ciel’a a zohl'adnenie obmedzení“ (Gergely a kol. 2002). Výsledky tohto výskumu však viedli aj k otázke, či pri vyvodzovaní záverov nedošlo $\mathrm{k}$ nesprávnej interpretácii detského správania $\mathrm{v}$ experimentálnych podmienkach. Je totiž možné, že deti pochopili správanie sledovaného aktéra ako snahu naučit' ich niečo nové a zaujímavé, ako snahu o odovzdanie nejakého dôležitého poznatku. $\mathrm{V}$ tom prípade by deti experimentálnu situáciu neinterpretovali tak, že majú predviest' svoje imitačné schopnosti, ale tak, že majú predviest' to, ako sa naučili, že lampa sa má zapínat' špecifickým spôsobom. Išlo by o pedagogickú situáciu, v ktorej sa deti učia od druhých, akým spôsobom vykonávat' isté činnosti, a pozorovaná osoba by pôsobila nielen ako vzor, ktorého správanie treba zopakovat', ale ako vzor, ktorého vykonávanie činností má byt' osvojené a zovšeobecnené. Dôležitou otázkou by tak bolo, do akej miery sú reakcie detí v experimentoch skúmajúcich vývin imitácie ovplyvnené interaktívnym kontextom, v ktorom experimentátor pôsobí ako expert. 


\section{Prirodzená pedagogika}

V kontexte uvedeného výskumu Csibra a Gergely (2009) sformulovali hypotézu prirodzenej pedagogiky, podl’a ktorej máme vrodenú predispozíciu automaticky rozpoznat' signály príznačné pre komunikačný kontext a od skorého veku sme schopní zamerat' svoju pozornost' na to, čo iní pokladajú za relevantné, a následne to spracovat' a uložit' v pamäti na d'alšie použitie. Jedným z predpokladov hypotézy prirodzenej pedagogiky je, že l'udia sú špecificky adaptovaní na to, aby boli schopní efektívne získavat' poznatky od iných a predávat' ich d'alším členom skupiny, ked’že prirodzený výber uprednostnil tých jednotlivcov, ktorí mali predispozíciu lepšie sa prispôsobit' l'udskej ekologickej nike, v ktorej zohrávali čoraz dôležitejšiu úlohu produkty materiálnej a duchovnej kultúry. Prirodzená pedagogika vychádza z teórie relevancie (Sperber a Wilson 1986) a z ostenzívno-inferenčného modelu komunikácie, v ktorom informujúci aktér dáva adresátovi ostenzívne signály, že ho chce oboznámit's niečím dôležitým, a na druhej strane adresát sa na základe inferenčných postupov usiluje pochopit' zmysel toho, čo je komunikované. Z pohl'adu prirodzenej pedagogiky a teórie relevancie by tak v prípade vyššie uvedených experimentov (Meltzoff 1988) išlo o situácie, v ktorých aktér vykonávajúci demonštráciu chce zviditel'nit' svoj zámer komunikovat' istú dôležitú informáciu prostredníctvom ostenzívnych signálov (ako napríklad očný kontakt a oslovenie) a na druhej strane diet’a chápe, že daný aktér má istý komunikačný zámer a chce informovat' o niečom relevantnom. Hypotéza prirodzenej pedagogiky bola pomerne úspešne testovaná v roku 2013 (Király a kol. 2013), ked’ experimenty potvrdili predpoklad, že deti majú vyššiu tendenciu imitovat' zapínanie lampy čelom v prípade, že demonštrácii predchádzali ostenzívne signály, príznačné pre komunikačný kontext. Zdá sa teda, že prirodzená pedagogika ponúka vhodné vysvetlenie správania detí počas experimentov, ktoré skúmajú skoré prejavy imitácie.

Pre hlbšie pochopenie pozorovaného fenoménu je zmysluplné podrobnejšie analyzovat' a skúmat' jednotlivé schopnosti a mechanizmy, ktoré umožňujú l'ud’om vstupovat' do interakcií, v ktorých dochádza k zámernému učeniu. Okrem schopnosti rozpoznat' ostenzívne signály a chápat' spoločný rámec, v ktorom diet’a a „,vzor“ (v prípade experimentov dospelá osoba) zameriavajú pozornost' na tie isté prvky, by diet’a malo byt' schopné pochopit' aj štruktúru činnosti, ktorá je predmetom učenia. Na základe uvedených experimentov (napr. Gergely a kol. 2002) môžeme povedat', že diet'a by malo byt' schopné rozpoznat' zámer činnosti, teda ciel', ktorý chce „vzor“ dosiahnut', a malo by byt' schopné vytvorit' si predikčný model činnosti, ktorý by pozorovanej osobe umožnil dosiahnut' ciel' najjednoduchším spôsobom. Diet’a by malo byt' schopné porovnat' vykonanú činnost's takýmto modelom a rozpoznat', čo je nové, prekvapivé, čo sa vymyká predikcii. V prípade, že dôjde k predikčnej chybe, tak rozdiel treba d'alej spracovat' a zobrat' pri tom do úvahy okolnosti, či aktérovi nejaká 
prekážka bráni alebo nebráni vykonat' činnost' efektívne. Ak bráni, tak treba predpokladat', že rozdiel medzi predpokladaným a vykonaným správaním aktéra nie je spôsobený zámerne. Ak prekážku nemožno rozpoznat', je vhodné predpokladat', že správanie bolo zámerné, nepredvídané kroky treba považovat' za signifikantné a je vhodné zapamätat' si ich. O dospelej osobe sa totiž predpokladá, že je expert, oplatí sa jej dôverovat', a ak signalizuje komunikáciu, tak je jej správanie motivované kooperatívnym zámerom dat' diet'at'u vediet' niečo informačne hodnotné. Prenos poznatkov predpokladá, že deti sú schopné rozpoznat', od koho sa učit' (ohodnotenie dôveryhodnosti a kompetentnosti), kedy sa učit' (rozpoznanie komunikačného kontextu) a čo sa učit' (rozpoznat', čo expert pokladá za relevantné).

Podl'a autorov, ktorí tento prístup obhajujú, teória prirodzenej pedagogiky umožňuje vysvetlit' viacero problémov vývinovej psychológie. Pomáha podla nich napríklad objasnit' chybu A non B, ktorú robia deti vo veku okolo desat' mesiacov. Túto chybu prvýkrát experimentálne skúmal Piaget (1954) v súvislosti s detským porozumením trvalému charakteru predmetov. Počas habituácie diet’a sleduje, ako experimentátor opakovane ukrýva predmet pod jednu z dvoch škatúl', pod škatul'u A, a diet'at'u sa po každom ukrytí darí predmet nájst'. V testovacej fáze experimentátor ukryje predmet pod krabicu B, no deti napriek tomu, že videli, ako bol predmet ukrytý na novom mieste, hlaadajú predmet stále pod krabicou A. Topál a kol. (2008) sa pokúsili reinterpretovat' experiment na základe teórie prirodzenej pedagogiky a ukázali, že na správanie diet’ata mal výrazný vplyv ostenzívny komunikačný kontext. Podla záverov ich výskumu možno povedat', že daná situácia predstavuje pedagogický kontext, v ktorom dochádza $\mathrm{k}$ prenosu poznatkov, pričom pozorovaný efekt je dôsledkom aktivácie príslušných mechanizmov učenia. $Z$ tejto perspektívy dospelý človek (expert) diet’at’u oslovením a očným kontaktom signalizuje (ostenzia), že sa o predmete, na ktorý sústred'uje svoju pozornost' (referencia), ide naučit' niečo dôležité (relevancia), čo si má zapamätat' a zovšeobecnit'. Diet’a sa počas habituácie naučí, že predmet sa nachádza na mieste A, a preto ho tam hladá. Chyba v tom prípade nie je ani tak prejavom nedostatočnej schopnosti inhibovat' motorický plán vytvorený počas úvodnej fázy experimentu, ale je skôr prejavom učenia a zovšeobecnenia, pričom je do značnej miery spôsobená vplyvom ostenzívneho komunikačného kontextu.

Za pomoci teórie prirodzenej pedagogiky možno vysvetlit' aj d'alšiu zaujímavú črtu l’udského správania, ktorou je tendencia k takzvanej prílišnej imitácii (overimitation). Ako príklad môžeme uviest' experimenty, $\mathrm{v}$ ktorých troj- až pät'ročné deti počas familiarizačnej fázy sledovali, ako experimentátor otvára „zvláštnu skrinku“ (puzzle box) spôsobom, ktorý obsahuje evidentne irelevantné kroky (Lyons a kol. 2007). Skrinky boli pre deti nové, no boli vyrobené z priehl'adnej hmoty, aby bolo zrejmé, že niektoré prvky sú s ostatnými spojené len náhodne a pri otváraní skrinky nemajú 
kauzálnu úlohu. Výsledky experimentov ukázali, že ked' mali deti v testovacej fáze otvorit' predmet samé (po tom, ako experimentátor opustil miestnost'), vykonávali aj nadbytočné kroky, a to napriek tomu, že v prípade použitia známych predmetov vedeli vel'mi dobre určit', ktoré činnosti sú kauzálne relevantné, a ktoré nie sú. Podl'a Lyonsa a kol. (2007), ked’ si deti vytvárajú reprezentácie kauzálnej štruktúry objektov, majú silnú tendenciu prisudzovat' zmysluplnost' všetkým zámerným krokom, ktoré pri demonštrácii predvádza osoba v pozícii „vzoru“.

Výskum prílišnej imitácie viedol k záverom, že ide o špecificky l'udskú črtu, ked’že napríklad šimpanzy postupovali pri riešení podobných úloh efektívnejšie, neopakovali činnosti bez zrejmého zmyslu a snažili sa dosiahnut' odmenu čo najrýchlejšie (napr. Horner a Whiten 2005). Tomasello $(1999,30)$ poukázal na to, že kým deti sa snažia zopakovat' pri dosahovaní ciel’a aj spôsob, akým bola daná činnost' vykonaná, šimpanzy sa zameriavajú pri zopakovaní činnosti najmä na čo najefektívnejšie dosiahnutie ciel'a a neopakujú správanie, ktoré je v tejto súvislosti nadbytočné. Šimpanzy teda neimitujú nové spôsoby pri dosahovaní ciel'ov, ale pri hl’adaní najlepšieho riešenia pomocou „pokusov a omylov“ používajú spôsoby, ktoré už sú v ich motorickom repertoári. Ked' sa šimpanzy učia činnosti od iných, používajú emuláciu, teda sa zameriavajú na dosiahnutie ciel'a čo najefektívnejším spôsobom, zatial' čo deti používajú imitáciu, teda sa zameriavajú aj napodobňovanie štruktúry činnosti samej.

K prekvapivým výsledkom viedol výskum McGuiganovej a kol. (2011), ktorý ukázal, že tendencia kopírovat' irelevantné činnosti s vekom neklesá, ale naopak rastie - predškoláci ich opakovali častejšie ako dvojročné deti, no dospelí imitovali nadbytočné prvky ešte častejšie. Práve zvláštna tendencia preberat’ aj formy správania, pri ktorých nie je priamo zrejmé, na dosiahnutie akého ciel’a sa zameriavajú, mohla vytvorit' predpoklady na kumuláciu kultúrnych poznatkov. Je vhodné predpokladat', že na učenie sa zložitých činností, ktoré sú výsledkom kumulácie poznatkov v priebehu mnohých generácií, nepostačuje stratégia emulácie, ale výhodu predstavuje schopnost' na základe dôvery $\mathrm{k}$ expertom preberat' aj také formy správania, ktoré pôsobia ako nejasné (opaque). Mohla sa stat' prekvapivo výhodnou v spoločnosti, v ktorej sa nástroje postupne stávali komplexnejšími, ich výroba trvala dlhšie, skladala sa z viacerých krokov (postupne sa vyrábali nástroje na to, aby sa pomocou nich vyrobili d'alšie nástroje) a zámer jednotlivých krokov tak osobe v pozícii žiaka nemusel byt' vôbec zrejmý. Zdá sa, že práve vd’aka tendencii k prílišnému imitovaniu a mechanizmom umožňujúcim efektívne kultúrne učenie, ktoré popisuje teória prirodzenej pedagogiky, sú l'udia schopní pomerne rýchlo preberat' naakumulované poznatky. $\mathrm{V}$ tejto súvislosti možno podotknút', že uvedený typ sociálneho učenia, pri ktorom nie je dôležitý len „obsah“ (ako splnit' ciel'), ale aj „forma“ (ktorá nesie informáciu o tom, ako má byt' činnost’ vykonávaná) zjavne súvisí aj s vývinom normativity. 


\section{Metareprezentácie}

Interakcie, v ktorých dochádza ku kultúrnemu učeniu, majú komplexnú štruktúru a dôležitú úlohu v nich zohráva spätná väzba. Osoba v pozícii učitel’a a osoba v pozícii žiaka navzájom sledujú svoje správanie, monitorujú či sústred'ujú svoju pozornost' na tie isté prvky. Navzájom na seba reagujú, učitel' upravuje svoje správanie tak, aby umožnil efektívny prenos informácí́. V pedagogickej situácii nejde len o zámer informovat' žiaka o niečom relevantnom, ale učitel' chce, aby žiak vedel, že ho informuje o niečom relevantnom (2. stupeň intencionality). Diet’a by malo chápat' tento komunikačný zámer (žiak chápe, že učitel' chce, aby si osvojil predvedenú činnost'), a teda by malo mat' pomerne rozvinutú teóriu mysle. Je zrejmé, že úspešná interakcia vyžaduje od oboch aktérov aj schopnost' reprezentovat' mentálne stavy (reprezentácie) iných - tak na strane pôvodcu, ako aj na strane príjemcu. Na strane pôvodcu treba okrem signalizovania komunikačného zámeru kontrolovat', či bol komunikačný zámer rozpoznaný, či žiak pochopil, že činnost', ktorú učitel' vykonáva, vyjadruje niečo dôležité, čo si treba osvojit', pomerne presne zapamätat' a použit' v iných podobných kontextoch. Na strane príjemcu zasa úspešná interakcia vyžaduje, aby bol schopný rozpoznat' učitel'ov komunikačný zámer, aby bol schopný zamerat' pozornost' na relevantnú činnost', aby rozpoznal jej štruktúru, vytvoril si pomerne abstraktný model činnosti, uložil si ho v pamäti a vo vhodnej situácii ho znovu aktivoval. Aj z dôvodu, že tento typ interakcie vyžaduje vzájomné reprezentovanie vnútorných stavov jednotlivých aktérov, je podla mňa vhodné použit' pri ozrejmení procesov umožňujúcich prenos kultúrnych poznatkov koncepciu metareprezentácií.

Za metareprezentácie vo všeobecnosti môžeme pokladat' komplexné reprezentácie, ktoré umožňujú reprezentovat' obsah iných reprezentácií. (Sperber 2000,117). Zohrávajú dôležitú úlohu napríklad v súvislosti so schopnost'ou chápat' mysle iných, teda v situáciách, v ktorých je vhodné použit’ teóriu mysle, ked’že tá si vyžaduje reprezentovanie toho, ako reprezentujú svet iní aktéri. Teória metareprezentácií bola rozvinutá práve v kontexte výskumu tejto schopnosti a jej aplikácia viedla k niekol'kým zaujímavým výsledkom, napríklad pri hl'adaní najskorších prejavov schopností príznačných pre typický vývin teórie mysle. V prípade autizmu bola pozorovaná súvislost' medzi zníženou schopnost’ou chápat' mysle iných (prejavujúcou sa ako nižšia úspešnost' pri riešení testu mylných presvedčení (Baron-Cohen a kol. 1985)) a výrazne zníženou tendenciou detí trávit' čas symbolickou hrou (Ungerer a Sigman 1981). Vysvetlenie vzt’ahu medzi oboma schopnost’ami navrhol Leslie (1987) práve na základe metareprezentačnej povahy a štruktúrnej podobnosti predstieranej hry ${ }^{1}$ (pretend play)

${ }^{1} \mathrm{~V}$ slovenskej odbornej literatúre je zaužívaný preklad „predstieraná hra“ (napr. preklad práce od Botterilla a Carruthersa (2008)), no dalo by sa uvažovat' o tom, či nie je vhodnejšie používat' termín „hra s predstavami“. Oba preklady však majú svoje nevýhody - „hra s predstavami““ má príliš široký 
a prisudzovania presvedčení. Pokúsim sa nadviazat' na toto riešenie a ukázat', že vzhl'adom na výsledky novšieho výskumu koncepciu metareprezentácií možno aplikovat’ aj na procesy umožňujúce zámerné učenie a kumuláciu kultúrnych poznatkov,. Využijem pri tom užšie vymedzenie metareprezentácí́ zakladajúce sa na práci Leslieho (napr. 1987, 1994). ${ }^{2}$ Metareprezentácie majú komplexnú štruktúru, ktorá vyžaduje usúvzt'ažnenie reprezentácií na rôznom stupni abstraktnosti. Základné prvky sú: aktér - postoj - obsah. Obsahu zodpovedá vzt’ah medzi primárnou a sekundárnou reprezentáciou - primárna reprezentácia je interpretovaná na základe obsahu sekundárnej reprezentácie. ${ }^{3}$ Jedným z komponentov takto ponímaných metareprezentácií sú primárne reprezentácie, ktoré majú priame sémantické spojenie so svetom, sú transparentné a platí, že adekvátne reprezentujú svet vtedy, ked' situácia, v ktorej sa subjekt práve nachádza, zodpovedá obsahu percepcie. Sekundárne reprezentácie nereprezentujú stav vecí tu a teraz a nemajú priamy kauzálny vzt’ah $\mathrm{k}$ svetu, sú schopné reprezentovat' jedine vd'aka kauzálnemu spojeniu, ktoré mali príslušné primárne reprezentácie, preto o nich možno hovorit' aj ako o oddelených (decoupIed) od reality (Perner 1991, 7). Oddelený charakter týchto reprezentácií umožňuje použit' ich v novej situácii, a tak ich interpretovat' - priradit' im napríklad isté objekty v aktérovom referenčnom rámci, na ktoré môžu na základe svojho obsahu a podmienok splnitel'nosti odkazovat'.

Na ozrejmenie môžeme ako príklad predstieranej hry uviest' situáciu, v ktorej sa diet’a (aktér) hrá (postoj) so škatul'kou (primárna reprezentácia), ktorá preň predstavuje auto (sekundárna reprezentácia). Dalo by sa povedat', že tá škatul'ka je auto, prípadne, že škatul'ka reprezentuje auto. Keby sme sa na túto situáciu pozreli z pozície Leslieho teórie metareprezentácií, mohli by sme povedat', že pri tomto type hry diet'a predstiera, že A (primárna reprezentácia - škatul'ka) je B (sekundárna, oddelená reprezentácia - auto), a teda interpretuje A na základe B. Takáto forma hry, ktorá sa typicky prejavuje vo veku od 18 mesiacov, je možná práve vd'aka využitiu metareprezentačnej schopnosti, v ktorej zohráva klúčovú funkciu operátor „predstiera, že“ (resp. „predstavuje si, že“). Operátor označuje metareprezentačný kontext a je súčast’ou reprezentačných štruktúr, ktoré si vyžadujú interpretáciu oddelených repre-

obsah a ,predstieraná hra“ má zas isté nežiaduce konotácie. Často však pôsobí vhodnejšie povedat’ „Diet’a si predstavuje, že škatul'ka je auto,“ ako „Diet’a predstiera, že škatul'ka je auto.“ S predstieraním sa totiž spája zavádzajúce, klamlivé správanie, ktoré osoba vykonáva pred niekým iným. Použitie tohto termínu taktiež môže zvádzat' k interpretácii, že diet’a hru len predstiera. Deti však často vykonávajú túto hru bez ohl'adu na to, či ich niekto sleduje, a nepôsobí adekvátne povedat', že ide o zavádzajúce či klamlivé správanie. Ďalšou alternatívou by mohol byt' i termín „hra akože“ (Rybár, 2002).

${ }^{2}$ Leslie používa na ich označenie i termín M-reprezentácie.

${ }^{3}$ Pri vymedzení primárnych, sekundárnych reprezentácií a metareprezentácií sa budem pridŕžat' prác Leslieho (1987), Pernera (1991) a Recanatiho (2000). 
zentácií v novom kontexte (X predstiera, že A je B). Používanie metareprezentácí́ s podobnou štruktúrou umožňuje zvládnut' det'om vo veku 4 až 6 rokov test mylných presvedčení (známy aj ako Sally Anne test) (Wimmer a Perner 1983). Po prezentácii testu sú deti schopné správne zodpovedat' otázku vd’aka tvoreniu metareprezentačnej konštrukcie: Sally (aktér) si myslí, že (postoj) na scéne (primárna reprezentácia) je skrytý predmet na pôvodnom mieste (sekundárna reprezentácia).

Nazdávam sa, že túto štruktúru možno odhalit' aj v prípade mechanizmov podmieňujúcich interakcie príznačné pre prirodzenú pedagogiku. V situáciách, ked’ si diet’a osvojuje (v interakcii s inými) koncept predstierania, alebo „hry akože,“ chápe, že táto škatul'ka môže mat' aj inú funkciu, ako je tá zrejmá - v rámci hry môže škatul'ka predstavovat' napríklad aj auto. Pri osvojovaní predstieranej hry sa diet’a učí, že istá činnost' alebo predmet môže nadobúdat' aj inú funkciu, ako tú zrejmú, alebo inak povedané, diet’a sa učí, že môže aplikovat' sekundárne reprezentácie na nové predmety. Podobne aj v prípade úspešnej pedagogickej interakcie by diet'a malo pochopit', že daná činnost' má aj inú funkciu, ktorá nie je priamo viditel'ná, no je dôležité si ju osvojit'. Mechanizmus oddelenia aj $\mathrm{v}$ tomto prípade prispieva $\mathrm{k}$ vytvoreniu oddelenej reprezentácie činnosti, ktorú možno použit' v novom kontexte, podobne ako sa oddelené reprezentácie môžu použit' v prípade predstieranej hry.

Štruktúra metareprezentácií okrem obsahu, ktorého nositel'mi sú primárne a oddelené reprezentácie, vyžaduje aj komponent vyjadrujúci postoj k obsahu. Postoj úzko súvisí komunikačným zámerom (Sperber a Wison 1986), no v prípade predstierania nemusí byt' tento vzt'ah zrejmý. Do popredia vystupuje v situáciách, ked' sa deti učia hrat' v interakcii s druhými aktérmi. Pri osvojovaní postoja „predstierat', že" $\mathrm{k}$ obsahu propozície „A je B“, treba rozpoznat', že „expert“ nerobí chybu, nepokúša sa komunikovat' nepravdivú výpoved', a ani to nie je pokus o pravdivé informovanie o tom, že A je v skutočnosti B. Ked' v tomto type situácií aktér povie, že A je B - škatul'ka je auto, tak pre správne porozumenie treba pochopit' komunikačný zámer - „hrajme sa (predstierajme, predstavujme si), že A je B.“ V prípade pedagogickej interakcie komunikačný zámer signalizuje práve ostenzia, o ktorej by sme mohli povedat' aj to, že pôsobí ako mechanizmus oddelenia (decoupler). V prípade, že je komunikačný zámer rozpoznaný, tak diet’a pochopí, že táto činnost' (primárna reprezentácia) predstavuje príklad dôležitého typu činnosti, a preto má byt' plán tejto činnosti rozpoznaný, „oddelený“ a uložený v pamäti na d'alšie použitie. Analogicky k predstieranej hre, v situáciách, ked' diet’a vykonáva činnost', ktorú sa naučilo, aplikuje abstraktnú reprezentáciu na prvky v pôvodnom alebo v novom kontexte.

Podobne ako v prípade predstieranej hry i v situáciách, pri ktorých dochádza k zámernému učeniu, zohráva zásadnú úlohu schopnost' vytvárat' si abstraktné, oddelené reprezentácie činností. Tým, že je v prípade oddelených reprezentácií prerušené 
priame sémantické spojenie (podobne ako v prípade predstieranej hry), však môže dôjst' $k$ tomu, že prestáva byt' zrejmé, na dosiahnutie akého ciel'a činnosti slúžia, resp. akú funkciu majú jednotlivé kroky plánu činnosti pri dosahovaní ciel'a. Proces tvorenia oddelených reprezentácií sa tak vzt’ahuje skôr na plány jednotlivých činnosti, ako len na činnosti ponímané ako prostriedok na dosiahnutie istého ciel’a. Úspešná pedagogická interakcia tak vedie $\mathrm{k}$ tomu, že diet’a by malo byt' schopné vytvorit' si pomerne abstraktný plán činnosti, o ktorom môžeme hovorit' ako o reprezentácii, ktorej obsah je vymedzený istými podmienkami splnitel'nosti s ohl'adom nielen na dosiahnutie ciel'a, ale aj s ohl'adom na spôsob, akým je činnost' vykonaná. Z pohl'adu prirodzenej pedagogiky možno za príklady tohto typu interakcie považovat' aj Meltzoffov experiment s lampou, Piagetov A non B, a aj situácie, v ktorých l'udia prejavujú prílišnú imitáciu. Na základe tejto koncepcie počas nich dochádza $\mathrm{k}$ tomu, že 1) expert (aktér) učí (postoj), že daný spôsob vykonávania činnosti (primárna reprezentácia) je príkladom dôležitého typu činností (sekundárna reprezentácia) a následne 2) žiak demonštruje, že vie v konkrétnej situácii vykonávat' abstraktný plán činnosti (dokáže interpretovat' dané prvky na základe oddelenej reprezentácie).

Tento typ sociálneho učenia umožňuje ozrejmit' kognitívne mechanizmy podmieňujúce schopnost' osvojovat' si činnosti, ktorých ciel' nie je evidentný, ktoré sú do značnej miery nepriehl'adné (opaque). Žiakovi pomáhajú pochopit', že daná činnost' je podl'a vzoru, od ktorého ju preberá a ktorému dôveruje, dôležitá, hoci jej zmysel je momentálne nejasný (žiak ho môže pochopit’ až neskôr). Na základe tejto koncepcie možno vysvetlit' aj pomere rýchle osvojovanie rôznych typov aktivít, pri ktorých sa v rôznych stupňoch prejavuje kauzálna a funkčná nepriehl'adnost' - od výroby nástrojov až po rôzne formy rituálov. Tendencia preberat' činnosti, ktoré nemajú jasný zmysel, môže pôsobit' iracionálne, no ako sa zdá, práve ona mohla prispiet' nielen k pokroku vo výrobných postupoch, ale i k vývinu normatívneho, ale aj symbolického myslenia. Takýto typ učenia prispieva na jednej strane $\mathrm{k}$ flexibilite, ktorá súvisí s novými spôsobmi interpretácie oddelených reprezentácií, na druhej strane zasa umožňuje zachovat' relatívnu stabilitu rozmanitých kultúrnych foriem, ked’že sa zameriava na osvojovanie plánov činností a na postupnosti jednotlivých krokov. Súhra tendencie $\mathrm{k}$ stabilite spolu s istou mierou flexibility by tak mohla zásadným spôsobom prispievat' $\mathrm{k}$ spomínanému efektu rohatky a západky, ktorý dal do pohybu kumulatívnu kultúru.

\section{Záver}

Pokúsil som sa ukázat', že teória metareprezentácií ponúka vhodný rámec na objasnenie kognitívnych mechanizmov, ktoré umožnili rozbehnút' kumulatívnu kultúru. Štruktúra komplexných metareprezentácií (jej základné prvky - postoj, primárne 
a sekundárne reprezentácie) môže pomôct' zretel'ne usúvzt'ažnit' tri kl'účové komponenty, na ktorých sa zakladá teória prirodzenej pedagogiky - ostenziu, referenciu a relevanciu. Ostenzia signalizuje komunikačný kontext, vyjadruje komunikačný zámer (postoj) aktéra. Referencia sa týka konkrétneho predmetu alebo činnosti, na ktorú „vzor“ v pedagogickom kontexte odkazuje (primárna reprezentácia). Relevancia súvisí s tým, že expert chce informovat' o niečom relevantnom, a síce že salientné prvky danej činnosti je vhodné zovšeobecnit', pretože sú príkladom dôležitého typu činností (sekundárna, oddelená reprezentácia). V tejto súvislosti možno spomenút', že istou explanačnou výhodou uvedenej koncepcie je aj to, že je kompatibilná s dvoma výraznými prúdmi vo vývinovej psychológii - $\mathrm{s}$ výskumom vychádzajúcim z princípov Piagetovho a z Vygotského prístupu. V Piagetovej teórii majú schémy podobnú funkciu ako oddelené, sekundárne reprezentácie a asimilácia je analogická s interpretáciou primárnych reprezentácií pomocou oddelených reprezentácií. Metareprezentácie však možno zosúladit' aj s Vygotského prístupom, ked’že pri ich tvorení zohráva dôležitú úlohu pochopenie sociálneho kontextu, typu interakcie medzi aktérmi a signalizácie komunikačných zámerov.

Uvedená koncepcia kultúrneho učenia umožňuje nielen popísat' šírenie rôznych foriem kultúry, ale ponúka aj odpoved' na otázku, aké reprezentácie a kognitívne mechanizmy umožňujú kumuláciu kultúrnych poznatkov (na rozdiel napr. od teórie mémov). Pokúsil som sa ukázat', že dôležitú úlohu zohráva mechanizmus oddelenia, ktorý súvisí so signálmi označujúcimi ostenzívny komunikačný kontext. V súčasnosti prebieha pomerne živá diskusia o vplyve týchto signálov najmä v súvislosti s fenoménom prílišnej imitácie. Ukazuje sa, že je pomerne zložité určit', do akej miery tento typ správania ostenzívne signály modulujú a akú majú presne funkciu pri preberaní poznatkov o používaní predmetov a vykonávaní činností s nejasnou funkčnou a kauzálnou štruktúrou. Výsledky experimentov často nie je jednoduché interpretovat' a navzájom teoreticky usúvzt'ažnit', čo môže byt' spôsobené aj tým, že spôsoby, ktorými sa ostenzia prejavuje u starších detí a dospelých, sa líšia od jednoduchších foriem, ktoré sú využivané $\mathrm{v}$ interakciách s predverbálnymi det'mi. Na označenie ostenzívneho komunikačného kontextu v komplexnejších situáciách sa využívajú aj implictné spôsoby, ktoré sa skúmajú zložitejšie.

V ostatných rokoch bolo publikovaných viacero štúdií, ktoré kritizujú teóriu prirodzenej pedagogiky a niektoré z jej základných princípov (napr. Nakao a Andrews 2014, Heyes 2016). Napriek kritike a návrhom alternatívnych vysvetlení však možno povedat' (aj na základe reprezentatívneho prehladu výskumu Hoehl a kol. 2019), že máme dostatočne silnú evidenciu v prospech vplyvu ostenzívneho komunikačného kontextu na schopnost' učit' sa od iných, na preberanie plánov činností, pri ktorých nie je zrejmý ich zámer a na tvorenie abstraktných plánov činností (oddelených reprezentácií). 
Možno teda povedat', že teória prirodzenej pedagogiky stále predstavuje zaujímavé riešenie problému podmienok rozvoja kumulatívnej kultúry. Jednou z výhod navrhnutého prepojenia s teóriou metareprezentácií je i to, že umožňuje skúmat' schopnosti príznačné pre prenos poznatkov už u predverbálnych detí, no umožňuje aj porovnat' ich s inými druhmi a odhalit' rozdiely a špecificky l'udský charakter zámerného učenia, ked'že schopnost' tvorit' metareprezentácie predchádza používanie gramatického jazyka. Predpokladám, že tento prístup by okrem usúvzt’ažnenia výsledkov z rôznych oblastí výskumu mohol prípadne prispiet' i $\mathrm{k}$ formulovaniu d’alších otázok a hypotéz o tom, čo mohlo spustit' kumulatívnu kultúru, a teda čo prispieva $\mathrm{k}$ „l'ludskej výnimočnosti.“

\section{Literatúra}

BARON-COHEN, S., LESLIE, A. M., FRITH, U. (1985): Does the autistic child have a "theory of mind”. Cognition, 21 (1), 37 - 46. DOI: https://doi.org/10.1016/0010-0277(85)90022-8

BOTTERILL, G., CARRUTHERS, P. (2008): Filozofia psychológie. Bratislava: Európa.

CSIBRA, G., GERGELY, G. (2009): Natural pedagogy. Trends in cognitive sciences, 13 (4), 148 153. DOI: https://doi.org/10.1016/j.tics.2009.01.005

DAWKINS, R. (2016): The selfish gene. Oxford: Oxford University Press.

DENNETT, D. C. (1990): Memes and the exploitation of imagination. The Journal of Aesthetics and Art Criticism, 48 (2), 127 - 135. DOI: https://doi.org/10.2307/430902

GERGELY, G., BEKKERING, H., KIRÁLY, I. (2002): Rational imitation in preverbal infants. Nature, 415 (6873), 755 - 755. DOI: https://doi.org/10.1038/415755a

HEYES, C. (2018): Cognitive gadgets: The cultural evolution of thinking. Cambridge (MA) - London: Harvard University Press.

HILL, K., BARTON, M., HURTADO, A. M. (2009): The emergence of human uniqueness: Characters underlying behavioral modernity. Evolutionary Anthropology: Issues, News, and Reviews: Issues, News, and Reviews, 18 (5), 187 - 200. DOI: https://doi.org/10.1002/evan.20224

HISCOCK, P. (2014): Learning in lithic landscapes: a reconsideration of the hominid "toolmaking" niche. Biological Theory, 9 (1), $27-41$.

HOEHL, S., a kol. (2019): 'Over-imitation': A review and appraisal of a decade of research. Developmental Review, 51, 90 - 108. DOI: https://doi.org/10.1016/j.dr.2018.12.002

HORNER, V., WHITEN, A. (2005): Causal knowledge and imitation/emulation switching in chimpanzees (Pan troglodytes) and children (Homo sapiens). Animal cognition, 8 (3), 164 181. DOI: https://doi.org/10.1007/s10071-004-0239-6

KIRÁLY, I., CSIBRA, G., GERGELY, G. (2013): Beyond rational imitation: Learning arbitrary means actions from communicative demonstrations. Journal of experimental child psychology, 116 (2), 471 - 486. DOI: https://doi.org/10.1016/j.jecp.2012.12.003

LALAND, K. N., GALEF, B. G. (eds.) (2009): The question of animal culture. Cambridge (MA) London: Harvard University Press.

LESLIE, A. M. (1987): Pretense and representation: The origins of "theory of mind." Psychological review, 94 (4), 412 - 426. DOI: https://doi.org/10.1037/0033-295X.94.4.412

LESLIE, A. M. (1994): Pretending and believing: Issues in the theory of ToMM. Cognition, 50 (1 3), 211 - 238. DOI: https://doi.org/10.1016/0010-0277(94)90029-9

LEWENS, T. (2006): Darwin. London: Routledge. 
LYONS, D. E., YOUNG, A. G., KEIL, F. C. (2007): The hidden structure of overimitation. Proceedings of the National Academy of Sciences, 104 (50), 19751 - 19756. DOI https://doi.org/ 10.1073/pnas.0704452104

MCGUIGAN, N., MAKINSON, J., WHITEN, A. (2011): From over-imitation to super-copying: Adults imitate causally irrelevant aspects of tool use with higher fidelity than young children. British Journal of Psychology, 102 (1), 1 - 18. DOI: https://doi.org/10.1348/000712610X493115

MELTZOFF, A. N. (1988): Infant imitation after a 1-week delay: long-term memory for novel acts and multiple stimuli. Developmental psychology, 24 (4), 470.

DOI: https://doi.org/10.1037/0012-1649.24.4.470

MESOUDI, A., WHITEN, A., LALAND, K. N. (2006): Towards a unified science of cultural evolution. Behavioral and brain sciences, 29 (4), $329-347$. DOI: https://doi.org/10.1017/S0140525X06009083

MESOUDI, A., THORNTON, A. (2018): What is cumulative cultural evolution? Proceedings of the Royal Society B: Biological Sciences, 285 (1880), 20180712. DOI: https://doi.org/10.1098/rspb.2018.0712

NAKAO, H., ANDREWS, K. (2014): Ready to teach or ready to learn: A critique of the natural pedagogy theory. Review of Philosophy and Psychology, 5 (4), 465 - 483. DOI: https://doi.org/10.1007/s13164-014-0187-2

PERNER, J. (1991): Understanding the representational mind. Cambridge (MA): MIT Press.

PIAGET, J. (1954): The construction of reality in the child. New York: Basic Books.

PINKER, S. (2003): How the mind works. London - New York - Toronto - Auckland: Penguin.

RECANATI, F. (2000): Oratio obliqua, oratio recta: an essay on metarepresentation. Cambridge (MA): MIT Press

RYBÁR, J. (2002): Epistemológia, kognitívna psychológia a teória mysle. In: Rybár, J. a kol. (eds.): Filozofia a kognitivne vedy. Bratislava: Iris.

SHETTLEWORTH, S. J. (2009): Cognition, evolution, and behavior. New York: Oxford University Press.

SPERBER, D. (2000): Metarepresentations in an evolutionary perspective. In: Sperber, D. (ed.): Metarepresentations: A multidisciplinary perspective. Oxford: Oxford University Press.

SPERBER, D., WILSON, D. (1986): Relevance: Communication and cognition. Cambridge (MA): Harvard University Press.

SŤAHEL, R. (2019): Lovelockov koncept udržatel'ného ústupu a jeho konzekvencie. Filozofia, 74 (5), 352 - 365. DOI: https://doi.org/10.31577/filozofia.2019.74.5.1

STERELNY, K. (2012): The evolved apprentice. Cambridge (MA): MIT Press.

STERELNY, K. (2016): Cumulative cultural evolution and the origins of language. Biological Theory, 11 (3), 173 - 186. DOI: https://doi.org/10.1007/s13752-016-0247-1

STOUT, D. (2011): Stone toolmaking and the evolution of human culture and cognition. Philosophical Transactions of the Royal Society B: Biological Sciences, 366 (1567), 1050 - 1059.

TOMASELLO, M. (1999): The cultural origins of human cognition. Boston: Harvard University Press.

TOMASELLO, M. (2009): The question of chimpanzee culture, plus postscript (Chimpanzee culture, 2009). In: Laland, K. N. - Galef B. G. (eds.): The question of animal culture. Cambridge (MA) - London: Harvard University Press, $198-221$.

TOMASELLO, M., KRUGER, A. C., RATNER, H. H. (1993): Cultural learning. Behavioral and brain sciences, 16 (3), 495 - 511. DOI: https://doi.org/10.1017/S0140525X0003123X

TOPÁL, J., a kol. (2008): Infants' perseverative search errors are induced by pragmatic misinterpretation. Science, 321 (5897), 1831 - 1834. DOI: https://doi.org/10.1126/science.1161437 
UNGERER, J. A., SIGMAN, M. (1981): Symbolic play and language comprehension in autistic children. Journal of the American Academy of Child Psychiatry, 20 (2), 318 - 337. DOI: https://doi.org/10.1016/S0002-7138(09)60992-4

WIMMER, H., PERNER, J. (1983): Beliefs about beliefs: Representation and constraining function of wrong beliefs in young children's understanding of deception. Cognition, 13 (1), $103-128$ DOI: https://doi.org/10.1016/0010-0277(83)90004-5

WILSON, E. O. (1975): Sociobiology. Cambridge (MA): Belknap / Harvard University Press

ZARKA, Y. C. (2018): Má ešte pojem l'udská prirodzenost' zmysel? Filozofia, 73 (10), 777 - 789.

Táto práca vznikla v rámci projektu VEGA 2/0128/19 Interaktívny obrat a ako d’alej vo výskume sociálnej kognicie.

Juraj Bánovský

Filozofický ústav SAV

Klemensova 1

81364 Bratislava 1

Slovenská republika

e-mail: juraj.banovsky@savba.sk

ORCID ID: https://orcid.org/0000-0002-0757-5064 